\title{
Profitability Analysis of Fish Farming in Niger State, Nigeria
}

\author{
Ahmed Gomna*, Pawa, Dan-Azumi, Zakari Mamman \\ Department of Agricultural Education, Federal College of Education, P.M. B 39, Kontagora, Niger State, Nigeria.
}

How to cite this paper: Ahmed Gomna, Pawa, Dan-Azumi, Zakari Mamman (2020) Profitability Analysis of Fish Farming in Niger State, Nigeria. International Journal of the Science of Food and Agriculture, 4(3), 293-300.

DOI: $10.26855 /$ ijfsa.2020.09.009

Received: June 28, 2020

Accepted: July 22, 2020

Published: August 31, 2020

*Corresponding author: Ahmed

Gomna, Department of Agricultural Education, Federal College of Education, P.M. B 39, Kontagora, Niger State, Nigeria.

Email: agomna@yahoo.co.uk

\begin{abstract}
In the study of aquaculture, much attention has been focused on bio-technical aspects. Economic research is often neglected by researchers and fish farmers. This paper examined the profitability of fish farming in Niger State, Nigeria. Data was collected by means of semi-structured questionnaire administered to 90 fish farmers randomly selected from three Agricultural zones in Niger State. The study revealed that fish farming is profitable in Niger State as a result of positive net returns, high rate of incomes and benefit-cost ratios and, therefore capable of creating employment, generating income and improving the standard of living of the people. Fish farming should therefore be encouraged and supported. Support could be in the form of technical assistance or subsidies.
\end{abstract}

\section{Keywords}

Niger State, Aquaculture, Fish farming, Profitability, Cost-Return

\section{Introduction}

Fishermen in Nigeria have for generations practiced traditional methods of fish culturing in tidal pools and floodplains. The need to increase food supply especially animal protein gave rise to fish farming in the country. Fish farming (aquaculture) is a rational way of augmenting the dwindling fish supply from capture fisheries. However, the aquaculture sub sector has not been fully exploited in Niger State despite its high potentials. Despite the great potentials of low land (fadama) for the development of rice-cum-fish culture, only 0.37 ha out of 495,000 ha of available fadama is being cultured at experimental stage in Niger State [1].

One way of assessing aquaculture performance is to apply cost-benefit analysis. The analysis is essential to evaluate the viability of investment in aquaculture, determine the efficiency of resource allocation, improve existing management practices, evaluate new culture technology, assess market potential, and identify areas in which fish production would have high payoffs [2, 3]. The primary motivation of a commercial fish farm is profit making.

Profitability of a fish farm is dependent on level of yield, cost of production and farm price. The level of physical production is mainly dependent on stocking rate, survival rate and growth rate which are in turn affected by:

- bio-technical factors such as fertilization and feeding, mono or polyculture, different stocking and harvesting strategies;

- environmental factors such as water quality, diseases and predators; and

- physical facilities such as site selection, construction, soil condition and equipment used.

The cost of production relates to the level of input, the prices of inputs, the culture system, the size of operation, as well as the institutional factors such as costs of credit and marketing. The farm price of aquaculture products is usually affected by the size and quality of the product, the supply-demand situation for the product, the market structure and the existence of (if any) of governmental pricing policies [2]. Increases in yield, reductions in costs and increases in price, 
therefore, are the major means of increasing profits.

Although fish farms exist in Niger State, Nigeria [4, 5, 6, 7], there is little information on the costs and returns of fish farming in the state. The few studies $[8,9,10]$ on profitability in Niger State were conducted in some specific Local Government Areas of the state and did not cover the entire state. The current study was therefore undertaken to examine the profitability of fish farming in Niger State, Nigeria.

\section{Materials and Methods}

\subsection{Study Area}

Niger State is located between Latitudes $8^{\circ} 20^{\prime} \mathrm{N}$ and $11^{\circ} 30^{\prime} \mathrm{N}$ and Longitudes $3^{\circ} 30^{\prime} \mathrm{E}$ and $7^{\circ} 20^{\prime} \mathrm{E}$. The state covers a total land area of 76,000 $\mathrm{km}^{2}$ representing about $9 \%$ of Nigeria's total land area. This makes the state the largest in the country (Figure 1). According to 1991 census, Niger state has a population of 2,482,367 with a population density of 33 persons per sq km; the lowest in the country [11].

Niger state is an inland region that has abundant fresh water resources. The state has numerous, large, perennial water bodies which include major rivers like Niger, Kaduna and Gurara and, three giant man-made lakes-Kainji, Jebba, and Shiroro with an estimated water surface area of 436,196 ha [12].

The state is divided into three Agricultural zones as shown in Table 1, according to Agricultural zoning system of Niger State Agricultural Development Project (ADP). The three zones are made up of 25 Local Government Areas (LGAs) of Niger State.

Table 1. Agricultural zones with their LGAs

\begin{tabular}{cc}
\hline Zone & Local Government Areas (LGAs) \\
\hline A & Agaie, Bida, Edati, Gbako, Katcha, Lapai, Lavun, Mokwa \\
B & Bosso, Chanchaga, Gurara, Paikoro, Munya, Rafi, Shiroro, Suleja, Tafa \\
C & Agwara, Borgu, Kontagora, Magama, Mariga, Mashegu, Rijau, Wushsishi \\
\hline
\end{tabular}

\subsection{Sampling procedure and sample size}

A multi-stage sampling procedure was adopted in the selection of the sample size. In the first stage, three LGAs were purposively selected on the basis of the availability of fish farms from each Agricultural zone for the study, making a total of nine Local Government Areas. The LGAs selected were Bosso, Shiroro, Chanchaga, Lavun, Mokwa, Bida, Borgu, Kontagora and Magama (Figure 2). In the second stage, 10 fish farmers were selected randomly from each of the nine LGA making a total of 90 fish farmers.

\subsection{Method of Data Collection}

Semi-structured questionnaire was used in collecting data from fish farmers. Rural Rapid Appraisal (RRA) technique was also adopted during the field visits. This method involves gathering of information through visual observations, measurements and oral interviews of individuals or groups. Data was collected with the help of extension agents of ADP in the State. Data was collected in November, 2019.

\subsection{Profitability Analysis}

Profitability was determined by the following criteria:

- $\quad$ Net return, defined as gross revenue minus total cost. The gross or total revenue is the total product or output multiplied by the market price of output. A positive net return means the activity is profitable.

- Benefit-cost ratio, defined as net return divided by the total cost. A ratio of greater than 1.0 is thus the indication of profitable activity.

- Rate of farm income, defined as net return divided by gross revenue, times 100 . The larger the rate of farm income, the greater the production efficiency.

Opportunity cost of family labor was estimated from cost of hired labor in the area. Annual depreciation rates using the straight line method were used for fixed assets with salvage value assumed to be zero at the end of useful component life. Annual depreciation rate was therefore computed by dividing the cost of the asset by its expected years of economic life (useful life).

\subsection{Statistical Analysis}

Data was analyzed using descriptive statistics such as means, percentages, and frequency tables. 


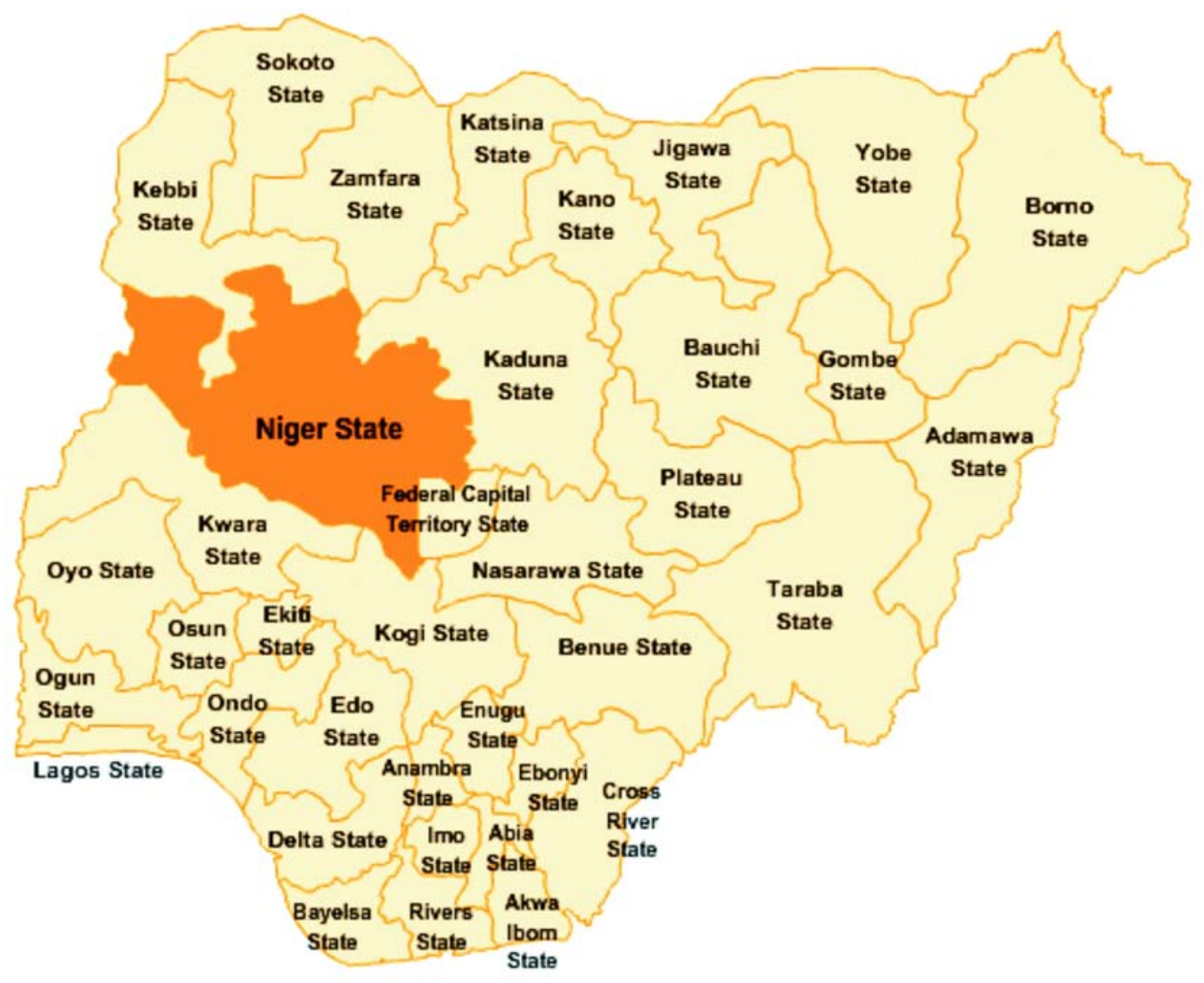

Figure 1. Map of Nigeria showing Niger state, the study area.
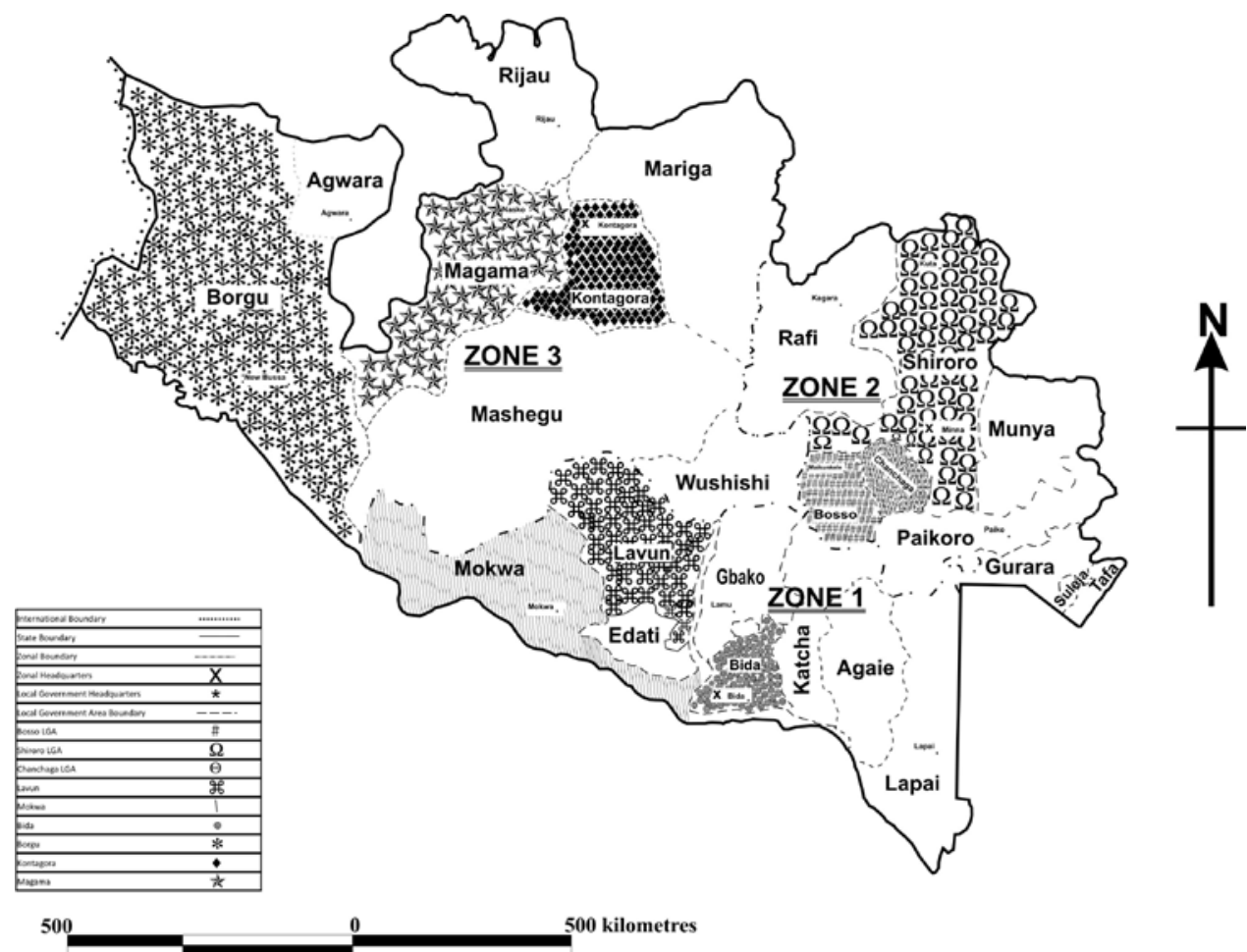

Figure 2. Map of Niger State showing the study areas. 


\section{Results}

\subsection{Socioeconomic characteristics of the fish farmers}

Socioeconomic characteristics of the fish farmers are presented in Table 2. Majority of the fish farmers (54\%) were within the age bracket of 31-45 years and about $88 \%$ of the farmers were males. The results showed that large percentages of the fish farmers (89\%) were married and about $43 \%$ of the farmers had family size of 6-10 persons. Large proportions (79\%) of the farmers had tertiary education and were mostly civil servants. Majority of the fish farmers (70\%) had less than six years experience in fish farming.

Table 2. Socioeconomic characteristics of the fish farmers

\begin{tabular}{|c|c|c|}
\hline Variable & Frequency & Percentage \\
\hline \multicolumn{3}{|l|}{ Age (years) } \\
\hline Less than 31 & 12 & 13.3 \\
\hline $31-45$ & 49 & 54.4 \\
\hline Above 45 & 29 & 32.2 \\
\hline \multicolumn{3}{|l|}{ Gender } \\
\hline Male & 79 & 87.8 \\
\hline Female & 11 & 12.2 \\
\hline \multicolumn{3}{|l|}{ Marital Status } \\
\hline Single & 9 & 10 \\
\hline Married & 80 & 89 \\
\hline Separated & 1 & 1 \\
\hline \multicolumn{3}{|l|}{ Household size } \\
\hline $1-5$ & 37 & 41.1 \\
\hline $6-10$ & 39 & 43.3 \\
\hline More than 10 & 14 & 15.6 \\
\hline \multicolumn{3}{|l|}{ Education status } \\
\hline No formal Education & 10 & 11.1 \\
\hline Primary education & 2 & 2.2 \\
\hline Secondary Education & 7 & 7.8 \\
\hline Tertiary Education & 71 & 78.9 \\
\hline \multicolumn{3}{|l|}{ Primary occupation } \\
\hline Farming & 31 & 34.4 \\
\hline Trading & 17 & 18.9 \\
\hline Civil servants & 40 & 44.4 \\
\hline Artisans & 2 & 2.2 \\
\hline \multicolumn{3}{|c|}{ Farming experience (years) } \\
\hline$<6$ & 63 & 70 \\
\hline $6-10$ & 20 & 22.2 \\
\hline More than 10 & 7 & 7.8 \\
\hline
\end{tabular}

Source: Field survey, 2019 


\subsection{Profitability of fish farming}

\subsubsection{Costs of fish production}

Costs of various inputs used in the fish production by farmers are presented in Table 3. Feed accounted for the highest cost (49\%) of fish production followed by cost of procuring (23\%) fingerlings. Inorganic fertilizer accounted for the lowest cost $(0.2 \%)$ of production.

\subsubsection{Profitability}

Total cost of $\mathrm{N} 227,453$ was incurred in producing 1,065 kg of fish per hectare per year by farmers (Table 4). Gross

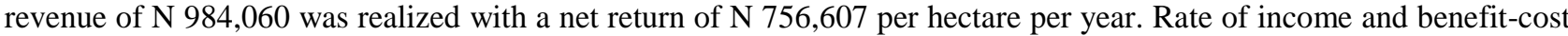
ratio were $77 \%$ and 3.3 , respectively.

\section{Discussion}

\subsection{Socioeconomic characteristics}

In fish farming, proper management determines the profitability of the aquaculture. The ability to make proper management of ponds is, in turn, largely a function of the farmer's age and education as well as his experience and degree of involvement in fish farming [13].

Table 3. Costs of fish production

\begin{tabular}{ccc}
\hline Cost item $\left(\mathrm{N} \mathrm{ha}^{-1} \mathrm{yr}^{-1}\right)$ & Mean & \% of Total cost \\
\hline Lime & $976 \pm 1,817$ & 0.4 \\
Organic Manure & $586 \pm 1,143$ & 0.3 \\
Inorganic Fertilizer & $500 \pm 1,832$ & 0.2 \\
Fingerlings & $52,044 \pm 67,261$ & 23 \\
Feed & $110,618 \pm 224,426$ & 49 \\
Labor & $26,056 \pm 16,847$ & 11 \\
Medication & $3,982 \pm 7,400$ & 2 \\
Total Variable Cost & $194,762 \pm 96,325$ & $\mathbf{8 6}$ \\
Depreciation of equipment & $1,009 \pm 128$ & 0.4 \\
Depreciation of Ponds & $31,682 \pm 71$ & 14 \\
Total Fixed Cost & $32,691 \pm 162$ & $\mathbf{1 4}$ \\
Total Cost & $227,453 \pm 177$ & $\mathbf{1 0 0}$ \\
\hline
\end{tabular}

Data is presented as mean \pm standard deviation. Nigerian Currency is Naira $(\mathrm{N}) .1$ United States Dollar = 362 Nigerian Naira in November, 2019.

Table 4. Costs and returns of fish production

\begin{tabular}{|c|c|}
\hline A. Mean production $\left(\mathrm{kg} \mathrm{ha}^{-1} \mathrm{yr}^{-1}\right)$ & 1,065 \\
\hline B. Average price $\left(\mathrm{N} \mathrm{kg}^{-1}\right)^{*}$ & 924 \\
\hline $\begin{array}{l}\text { C. Gross revenue }\left(\mathrm{N} \mathrm{ha}^{-1} \mathrm{yr}^{-1}\right) \\
\text { (AxB) }\end{array}$ & 984,060 \\
\hline D. Mean total cost $\left(\mathrm{N} \mathrm{ha}^{-1} \mathrm{yr}^{-1}\right)$ & 227,453 \\
\hline $\begin{array}{l}\text { E. Net return }\left(\mathrm{N} \mathrm{ha}^{-1} \mathrm{yr}^{-1}\right) \\
\qquad(\mathrm{C}-\mathrm{D})\end{array}$ & 756,607 \\
\hline $\begin{array}{l}\text { F. Rate of income (\%) } \\
\text { (E/C x 100) }\end{array}$ & 77 \\
\hline $\begin{array}{l}\text { G. Benefit - cost ratio } \\
\text { (E/D) }\end{array}$ & 3.3 \\
\hline $\begin{array}{l}\text { H. Average cost }\left(\mathrm{N} \mathrm{kg}^{-1}\right) \\
\text { (D/A) }\end{array}$ & 214 \\
\hline $\begin{array}{l}\text { I. Net return }\left(\mathrm{N} \mathrm{kg}^{-1}\right) \\
\qquad(\mathrm{B}-\mathrm{H})\end{array}$ & 710 \\
\hline
\end{tabular}

* Prevailing market price of fish. $\mathrm{n}=90$. 
The current study showed that fish farmers were in the middle and economically active age group (Table 2) suggesting that training the farmers in fish farming may be effective. The result compares favorably with the findings of [14, 15].

Majority of Aquaculture farmers had attained tertiary level of education as indicated in (Table 2). A higher level of education is necessary for improved farm management and use of new production technologies [13, 16]. The willingness of farmers to take risks and innovate also may increase with level of education. Human resource development is largely a function of literacy and educational attainment. Amongst farmers, literacy and education attainments help develop conceptual skill and also facilitate the acquisition of technical skill, which can have direct bearing on income generation, expenditure and saving activities. Veerina et al. [17] noted that factors such as literacy have a role in influencing yields through production decisions. There is a general consensus that education has a positive effect on agricultural productivity [18, 19], a high rate of illiteracy resulting in low farm efficiency [20, 21]. Atapattu [22] stated that fish farmers should be properly educated with respect to the importance of management. The development of aquaculture is limited by technological and biological knowledge, and the level of education and experience in a society [3].

Most of the fish farmers were civil servants and majority had less than 10 years experience in fish farming. Primary occupation may not provide full time employment and the income derived from it may be insufficient to provide adequate means of livelihood, hence secondary occupation which was fish farming. Farmer's income is a key measure reflecting economic security. A household is economically secure when it has the capacity to generate sufficient income to satisfy the basic needs of the family and to maintain or increase the goods necessary for the stability of the household economy [23].

The study revealed dominance of men in fish farming. Women engage more in fish processing, preservation and marketing in the study area. Majority of the fish farmers were married and had large household size. This could be due to religion and geographic location. Niger state is in the Northern part of Nigeria where Muslims are concentrated [24]. The majority of the farmers in the study area had Islam as their religion, which allows polygamy that could lead to more children suggesting that they had labors to work on the farm.

\subsection{Profitability of fish farming}

The study revealed positive net return, high rate of income and benefit-cost ratios indicating that fish farming is profitable in Niger State, Nigeria. Various studies [25, 26, 14, 27, 28, 29, 30, 31, 32, 33, 34, 35] have also shown that fish farming is a profitable business.

Profitability of a farm is dependent on level of yield, cost of production and farm price. Increasing yield, reducing costs and increasing market price could increase the profitability of fish ponds. Increasing stocking rate, survival rate and growth rate are the primary means of increasing production [2]. In order to increase the yield of fish ponds, farmers paid more attention to management techniques such as mortality reduction, liming, fertilization, feeding, water quality monitoring, control of predators and poaching.

The cost of production relates to the level of input, the prices of inputs, the culture system, the size of operation, as well as the institutional factors such as costs of credit and marketing. Although the total cost of production is higher with fertilization and supplementary feeding than without, the production cost per kg may be lower and the additional revenue generated may be higher than the additional cost involved. Using domestic and farm wastes for fish culture helped in reducing the cost of feed and fertilizer. This practice also helped in recycling wastes, thereby protecting the environment and at the same time contributing to food production.

The farm price of aquaculture products is usually affected by the size and quality of the product, the supply-demand situation for the product, the market structure and the existence of (if any) of governmental pricing policies [2]. Farmers produced large fish at harvest in order to obtain higher prices. Phased stocking so that harvesting occurs at desirable times with respect to demand and price of fish can also increase the price of fish received. Low quality, spoilage, and waste reduce the average price that the farmers receive. However, the quality of fish can be improved through proper preservation during transport.

\section{Conclusion}

The study revealed that fish farming is profitable in Niger State as a result of positive net returns, high rate of incomes and benefit-cost ratios and, therefore capable of creating employment, generating income and improving the standard of living of the people.

Fish farming should therefore be encouraged and supported. Support could be in the form of technical assistance or subsidies.

\section{Acknowledgement}

The authors wish to thank the Tertiary Education Trust Fund (TETFUND) for providing research grant. 


\section{References}

[1] Yaro, I. (2001). Development of rice-cum-fish model using Nile tilapia (Oreochromis niloticus) in Niger state. PhD Thesis. Federal University of Technology, Minna, Nigeria.

[2] Shang Y. C. (1990). Aquaculture Economic Analysis: An Introduction. Advances in World Aquaculture. Baton Rouge, World Aquaculture Society. Pp. 211.

[3] Tisdell, C. A. (1994). Socio-economic considerations in the development of aquaculture. In: Carney, D., (Ed.) Sustainable Rural Livelihoods. Papers presented at the Department for International Development's Natural Resources Advisers' Conference. pp. 139-153. London: DFID

[4] Gomna, A. (2006). The role of traditional aquaculture systems and fish in food security and livelihoods of fishing communities in two states in Nigeria. PhD Dissertation. Institute of Aquaculture, University of Stirling, Stirling, Scotland, UK.

[5] Ifejika, P. I., Ayanda, J. O., and Sule, A. M. (2007). Socio-Economic variables affecting Aquaculture practices in Borgu Local Government Area of Niger State, Nigeria. Journal of Agriculture and Social Research, 7(2): 20-29.

[6] Oladeji, J. O., Olutegbe, N. S., and Aina, I. M. (2018). Fish Farmers’ Access to Extension Information in Borgu Local Government Area of Niger State, Nigeria. Proceedings of the Annual Conference of the Agricultural Extension Society of Nigeria. 161-172.

[7] Sadiq, M. S., and Danasabe, K. M. (2015). Problems' and prospects of small-scale fish farming in Minna Agricultural Zone of Niger State, Nigeria, and its implications on increased Fish Food Security. International Journal of Agricultural Research and Review: 3(2): 157-160.

[8] Nnaji, J. C., Madu, C. T., and Raji, A. (2013). Profitability of Rice-Fish Farming in Bida, North Central Nigeria. Journal of Fisheries and Aquatic Science, 8: 148-153.

[9] Sadiq, M. S. (2014). Profitability of small scale fish farming in Minna Agricultural Zone of Niger state in Nigeria. Indian Journal of Economics and Development. 10(4): 382-386.

[10] Yisa, E., Mohammed, U. S., Adebayo, C., and Anaweta, P. U. (2015). Profitability analysis of catfish farming in Suleja local government area of Niger state, Nigeria. Journal of Agriculture and Food Science, 13(1): 1-10.

[11] Niger State Ministry of Information. (2003). This is Niger state. Minna: Niger State Ministry of Information.

[12] Azengi, A. (1995). Feasibility study on fisheries resources of Niger state, Minna, Nigeria: Niger state fisheries department.

[13] Panayotou, T., Wattanutchariya, S., Isvilanonda, S., and Tokrisna, R. (1982). The economics of catfish farming in central. Thailand. ICLARM TECHNICAL REPORTS 4.

[14] Adewuyi, S. A., Phillip, B. B., Ayinde, I. A., and Akerele, D. (2010). Analysis of Profitability of Fish Farming in Ogun State, Nigeria. J Hum Ecol, 31(3): 179-184.

[15] Tunde, A B., Kuton, M. P., Oladipo, A. A., and Olasunkanmi, L. H. (2015). Economic Analyze of Costs and Return of Fish Farming in Saki-East Local Government Area of Oyo State, Nigeria. J Aquac Res Development, 6(2): 2155-9546.

[16] Safina, N., Gertrude, A., Lawrance, O., Ronald, W., Alphonse, C., Samuel, O., Mbilingi, B., and Izaara, A. A. (2018). Profitability and Viability Analysis of Aquaculture Production in Central Uganda: A Case of Urban and Peri-Urban Areas. Asian Journal of Agricultural Extension, Economics \& Sociology, 22(4): 1-11.

[17] Veerina, S. S., Nandeesha, M. C., De Silva, S. S., and Ahmed, M. (1999). An analysis of production factors in carp farming in Andhra Pradesh, India. Aquaculture Research, 30: 805-814.

[18] Phillips, M. J. (1987). A comment on farmer education and farm efficiency: a survey. Economic Development and Cultural Changes, 35: 637-641.

[19] Phillips, M. J. (1994). Farmer education and farmer efficiency. Economic Development and Cultural Changes, 43: $149-165$.

[20] Ali, M. H., Akbar, M. A., and Rahman, M. H. (1982). Utilization of fish ponds Mymensingh district. Bangladesh Journal of Agricultural Economics, 5:103-114.

[21] Sadiq, M. S., Suleiman, A., Umar, M. S., Lawal, A. T., Singh, I. P., Isah, M. A., Maude, M. A., and Sallawu, H. (2015). Profit Efficiency and profit progress among small scale fish farmers in Niger State, Nigeria.MLE Econometric Frontier Function Approach. International Journal of Aquaculture, 5(45): 1-12.

[22] Atapattu, A. R. (1994). Community-based approaches to fisheries management: the role of marketing development and fisheries co-operatives in improving socio-economic conditions of small-scale fishermen. Proceedings of the Indo-Pacific Fishery Commission (IPFC) Symposium 8. Bangkog, Thailand: RAPA.

[23] CARE. (1998). Measuring the impact of CARE—Bangladesh projects using household livelihood food security framework. Dakar, Bangladesh: CARE.

[24] Falola, T. (1999). The history of Nigeria, London: Greenwood Press.

[25] Adeniyi, O. R., Omitoyin, S. A., and Aderibigbe, H. I. (2010). Profitability of aquaculture practices: empirical experience from farmers in Epe Local Government Area of Lagos state. Nigerian Journal of Fisheries, 7(1\&2): 117-125. 
[26] Adeogun, O. A., Alimi, T., and Adeyemo, R. (2012). Status, cost and profitability of aquaculture enterprises in Nigeria: implications for food security. International Journal of Agricultural Sciences, 2(1): 59-66.

[27] Busari, A. O. (2018). Economic Analysis of Homestead Fish Farming in Olorunda Local Government Area, Osun State, Nigeria. Nigerian Journal of Fisheries and Aquaculture, 6(2): 19-26.

[28] Ebukiba, S. E., and Anthony, L. (2019). Economic Analysis Of Cat Fish (Clariasgariepenus) Production in Karu Local Government Area, Nassarawa State, Nigeria. IOSR Journal of Agriculture and Veterinary Science, 12(3): 41-48.

[29] Hyuha, T. S, Bukenya, J. O., Twinamasiko, J., and Molnar, J. (2011). Profitability analysis of small scale aquaculture enterprises in Central Uganda. International Journal of Fisheries and Aquaculture, 2(15): 271-278.

[30] Idisi, P. D., Ebukiba, E. S., and Adamu, S. M. (2019). Profitability Analysis of Cat Fish Production in Kuje Area Council Federal Capital Teritory, Nigeria. IOSR Journal of Agriculture and Veterinary Science (IOSR-JAVS), 12(3): 31-37.

[31] Namonje-Kapembwa, T., and Samboko, P. (2020). Is aquaculture production by small-scale farmers profitable in Zambia? International Journal of Fisheries and Aquaculture, 12(1): 6-20.

[32] Nunoo, F. K. E., Asamoah, E. K., and Osei-Asare, Y. B. (2014). Economics of aquaculture production: a case study of pond and pen culture in southern Ghana. Aquaculture Research, 45: 675-688.

[33] Penda, S.T., Unaji, G. P., and Odoenmenem, 1. U. (2013). Profitability Analysis of Fish Production from concrete pond system in Benue State, Nigeria. International Journal of Research in Social Sciences, 2(4): 64-70.

[34] Thompson O. A. and Mafimisebi, T. E. (2014). Profitability of Selected Ventures in Catfish Aquaculture in Ondo State, Nigeria. Fisheries and Aquaculture Journal, 5(2): 1-7.

[35] Sogbesan, O. A., Suleman, U., and Madaki, M. J. (2015). Economics and Profitability Assessment of Medium Scale Catfish Farms in Yobe State, North East, Nigeria. IOSR Journal of Economics and Finance, 6(1): 24-30. 